\title{
Adequacy of the Electrical Conductivity Test Methodology for Millet Seeds
}

\author{
Luanna Karoline Rinaldi ${ }^{1}$, Diandra Javorski ${ }^{2}$, Maicon Javorski ${ }^{2}$, Ana Paula Mourão Simonetti ${ }^{2}$, \\ Tatiane Priscila Chiapetti ${ }^{1}$, Maria Eunice Lima Rocha ${ }^{1}$, Mayra Taniely Ribeiro Abade ${ }^{1}$, Camila Hendges ${ }^{1}$, \\ Cleonice Lubian ${ }^{1}$, Jaqueline de Araujo Barbosa ${ }^{1}$, Guilherme Mascarello ${ }^{1} \&$ Ivonei Perego ${ }^{1}$ \\ ${ }^{1}$ Universidade Estadual do Oeste do Paraná, Brazil \\ ${ }^{2}$ Centro Universitário FAG, Brazil \\ Correspondence: Tatiane Priscila Chiapetti, Universidade Estadual do Oeste do Paraná, Brazil. E-mail: \\ tatianechiapetti@gmail.com
}

Received: July 25, 2017

Accepted: September 3, $2017 \quad$ Online Published: October 15, 2017

doi:10.5539/jas.v9n11p130

URL: https://doi.org/10.5539/jas.v9n11p130

\begin{abstract}
Companies have sought to improve, more and more, the quality control of the seeds produced, improving tests that evaluate the vigor of the seeds with greater speed and precision. The objective of the present work was to study the effects of imbibition time on the results of the electrical conductivity test to evaluate the vigor of millet seeds and to correlate with the other tests carried out. Six seeds lots of the ADR300 cultivar with different vigor levels were used. Germination, first germination count, accelerated ageing, emergence and emergence speed of seedlings in sand and electrical conductivity with variations in water volume were performed $\left(50 \mathrm{And} 75 \mathrm{~cm}^{3}\right)$, during the imbibition time of 2, 4, 6 and 8 hours, at $25^{\circ} \mathrm{C}$. The time of 2 hours of the seed imbibition in $75 \mathrm{~cm}^{3}$ in water proved to be efficient to evaluate the vigor of millet seeds in all lots tested.
\end{abstract}

Keywords: physiological potential, Pennisetum americanum L., deterioration

\section{Introduction}

Millet (Pennisetum glaucum L.) is one of the most important grains in the world, being grains present high food value, used in animal feed and also in human food. Its planting area has been increasing significantly since it is a hedging option in no-tillage systems, due to its high amount of dry matter, resistance to water deficit and high biomass production (Carneiro, 2008; Vazquez, 2011).

The low physical and physiological quality of the commercialized seeds is one of the main problems of the present time, since the production of millet seeds with high physiological potential is essential for the proper establishment of seedlings in the field (Peske \& Novembre, 2010).

The physiological potential of the seeds is a reflection of a set of characteristics determined by the germination and vigor tests, which identify their capacity to present adequate performance when the seeds are exposed to different environmental conditions (Bhering, Dias, Vigial, \& Naveira, 2006). Therefore, the use of this information allows, in a safe way, to verify the behavior of the seeds, which directly influences the decision making for selection of lots with high and low vigor.

The vigor tests have been used mainly to identify differences associated with the performance of seed lots, during storage or after sowing, not detected by the germination test. Thus, they seek to highlight the lots with greater and less efficiency for the establishment of the stand under wide variation of the environment conditions (Marcos-Filho, Kiuti, \& Lima, 2009).

Among the tests of vigor, the electrical conductivity stands out as being a fast and efficient method of determining the physiological potential of seeds. It was initially developed for pea seeds and aims to indirectly assess the intensity of damage to cell membranes resulting from the seed deterioration process (Vieira \& Kryzanowski, 1999). In this test, the seeds are soaked in a certain volume of distilled water, under controlled temperature, during a pre-established period. Therefore, those with lesser vigor release higher amount of leachate, as a consequence of the lower structuring and selectivity of the membranes (Vieira \& Kryzanowski, 2002). 
Several factors may affect the results of the electrical conductivity test, such as: time and temperature of imbibition; Seed size; Initial seed water percentage, number of seeds in the sample; and the genotype (Vieira \& Kryzanowski, 1999; Martins et al., 2002; Gaspar \& Nakagawa, 2002; Dutra \& Vieira, 2006). In this way, has aroused the interest of technologists and seed researchers to study the methodology for different species. However, for millet seed, information on the specific methodology for conducting this test is not well defined in the literature.

In accordance with the foregoing, the present work has the objective of studying the effects of volume variations and imbibition time, on the results of the electrical conductivity test, to evaluate the vigor of millet seeds and to correlate with standard tests used.

\section{Material and Methods}

The experimental work was developed at the Laboratory of Seed Analysis of the Plant Production Department of the Luiz de Queiroz College of Agriculture of the University of São Paulo (ESALQ/USP), in Piracicaba-SP.

How was the different strength level evaluated? How were the seeds of one cultivar divided into six lots with different levels of vigor?

Six batches of millet seeds of the cultivar ADR300 were used. The lots were cultivated at different times and in different locations, resulting in different levels of vigor, which were determined by germination test, accelerated aging tests, first germination count, emergence, seedling emergence velocity in sand and electrical conductivity, Which was evaluated with variations of imbibition time and different volumes.

\subsection{Water Content (WC)}

The water content of the seeds (WC) was determined by the greenhouse method, dried at $105 \pm 3{ }^{\circ} \mathrm{C}$, for 24 hours, using two sub-samples of $5 \mathrm{~g}$ of seeds per batch (Ministry of Agriculture, Livestock and Supply, 2009).

\subsection{Electrical Conductivity (EC)}

For the conductivity test (EC), four replicates of 50 seeds of each batch, physically pure, were evaluated and their masses were measured with precision of two decimal places $(0.01 \mathrm{~g})$. The ingestion was done in plastic cups $\left(200 \mathrm{~cm}^{3}\right)$ and in each period the seeds were kept in a BOD (Biochemical Oxygen Demand) type incubator at $25{ }^{\circ} \mathrm{C}$. The treatments used were $50 \mathrm{~cm}^{3}$ and $75 \mathrm{~cm}^{3}$. At the end of each embedding time, the EC of the solution was determined by DIGIMED 21 conductivity meter readings. Except for the factors studied, the test was performed as described by Vieira and Krzyzanowski (1999).

\subsection{Germination $(G)$ and First Germination Count (FGC)}

Germination was conducted in four replicates of 50 seeds per batch. First, the seeds were distributed onsheets of paper towel and moistened with an amount of water equivalent to 2.5 times the mass of the dried paper, and then kept in a germinator at $25^{\circ} \mathrm{C}$.

Germination counts were performed at three days (first count) and seven days after sowing (Ministry of Agriculture, Livestock and Supply, 2009).

\subsection{Accelerated Aging (AA)}

It was performed by distributing seed samples in a single layer on a canvas suspended in a plastic box $(11 \times 11 \times$ $3 \mathrm{~cm}$ ) containing $40 \mathrm{~cm}^{3}$ of water. The boxes were then maintained in a BOD camera set at $41{ }^{\circ} \mathrm{C}$ for 96 hours (Marcos-Filho, 1999). After 96h incubation of the seeds, the germination test was started as previously described.

\subsection{Emergence (EMA) and Emergence Velocity Index (EVI) of Seedlings in Sand}

Four replicates of 50 seeds each of the batch were distributed on the surface of a layer of $5 \mathrm{~cm}$ with sand placed in plastic boxes and dimensions of $32 \times 28 \times 10 \mathrm{~cm}$.

After sowing, the boxes were kept in greenhouse and the cover was made with a layer of $3 \mathrm{~cm}$ of sand. Substrate wetting was performed with the amount of the water corresponding to $60 \%$ of the retention capacity.

The evaluations were done daily, registering the number of the seedlings emersed for each of the lot until the stabilization. To obtaining seedling emergence speed was calculated the seedling emergence velocity index (EVI) by means of Equation (1) as proposed by Manguire (1962): 


$$
E V E=(N 1 / D 1)+(N 2 / D 2)+\ldots+(N n / D n)
$$

Where,

EVI: index of seedling emergence velocity (dimensionless); N1, N2, .. Nn: number of seedlings emerge in the first, second, and last count, respectively; D1, D2, ... Dn: number of days from the first, second, to the last count.

At 14 days after sowing the test was concluded, also computing the average seedling emergence percentage for each of the lot. (After sowing 14 days the test was completed, computing, as well the average seedling emergence percentage for each of the lot).

\subsection{Statistical Analysis}

The analysis of the results of the evaluation of the physiological potential of the seeds was by a completely randomized experimental design. For the results obtained by the electrical conductivity test, we used the factorial scheme, volume $\times$ hours $\times$ lots $(2 \times 4 \times 6)$. After that, the significant differences between the means of each treatment were determined by Tukey's test $(\mathrm{p} \leq 0.05)$. Analyzes were performed in triplicate.

\section{Results and Discussion}

In Table 1 are presents the data of the physiological potentials of the six batches of millet seeds. The seeds presented initial water content between 9.0 and $10.2 \%$ and, after the accelerated ageing test, this value ranged from 14.1 to $15.2 \%$. Compliant with Marcos-Filho (2015), the tolerable limit of variation between samples is up to $2.0 \%$, in order to provide reliability of the results. It is worth mentioning that this parameter has a relation that seeds with higher water tenor are more likely to germinate in advance, which may compromise the results of the vigor tests (Silva \& Cicero, 2014).

Table 1. Results of water content at the beginning of the evaluations (WC) and after the accelerated aging test (WCAA), for six lots of millet seeds of cultivar ADR 300

\begin{tabular}{lll}
\hline Lots & $\mathrm{WC}(\%)$ & $\mathrm{WC}_{\mathrm{AA}}(\%)$ \\
\hline L1 & 9.6 & 14.1 \\
L2 & 9.0 & 14.5 \\
L3 & 9.3 & 15.2 \\
L4 & 9.4 & 14.8 \\
L5 & 9.9 & 14.8 \\
L6 & 10.2 & 15.0 \\
\hline CV*(\%) & 6.3 & 8.2 \\
\hline
\end{tabular}

Note. ${ }^{*} \mathrm{CV}=\overline{\text { Coefficient of variation. }}$

The seedling emergence index (EVI) is the evaluation of the number of emergent seedlings as a function of the observed time. Emergence of seedlings in sand (ESS) is the evaluation of the amount of seedlings emerged in a total of time evaluated using sand as substrate. The Accelerated Aging Test (AA) is a vigor test that integrates desired characteristics, is fast, economical, simple and useful for all species. This test is performed under conditions of high temperature and relative humidity of the air for short periods followed by a test of germination. More moist seeds will suffer greater deleterious effects of stress, due to the intensification of their metabolic activity (Copeland \& McDonald, 2001).

In Table 2 it can be observed that the percentage of seed germination was similar for all lots, ranging from 82 to $92 \%$. These values meet the standards for commercialization of millet seeds, where the minimum germination standard required is $75 \%$ (Ministry of Agriculture, Livestock and Supply, 2009). In agreement Marcos-Filho (2015), the germination test makes it possible to obtain the maximum germination potential of the seed lot, as it is carried out under controlled environment conditions. Therefore, the vigor comparison between seed lots with similar germination is recommended, since vigor tests detect differences in the physiological potential between seed lots not detected in the germination test.

In the accelerated aging test, emergence of seedlings in sand and in the rate of emergence speed of seedlings in sand, differences between the lots were observed (Table 2). In general, lots 1 and 3 presented higher and lower vigor, respectively. 
Table 2 shows that the test of first germination count did not show sensitivity to detect differences in vigor between the lots. It is important to stress that the vigor tests have specific evaluation principles. The physiological potential of the seeds is a reflection of a set of characteristics determined by the germination and vigor tests, which identify their capacity to present adequate performance when the seeds are exposed to different environmental conditions (Bhering, Dias, Vigial, \& Naveira, 2006).

Table 2. Results of germination (G) evaluated after 7 days, first germination count (FGC) evaluated after 3 days, accelerated aging (AA), seedling emergence (ESS), seeding rate of six lots of corn cultivar ADR 300

\begin{tabular}{llllll}
\hline Lotes & G (\%) & FGC (\%) & AA (\%) & ESS (\%) & EVI \\
\hline L1 & $83^{\mathrm{a}}$ & $77^{\mathrm{a}}$ & $81^{\mathrm{a}}$ & $92^{\mathrm{a}}$ & $13.39^{\mathrm{a}}$ \\
L2 & $84^{\mathrm{a}}$ & $70^{\mathrm{a}}$ & $70^{\mathrm{ab}}$ & $89^{\mathrm{ab}}$ & $13.53^{\mathrm{a}}$ \\
L3 & $83^{\mathrm{a}}$ & $75^{\mathrm{a}}$ & $59^{\mathrm{b}}$ & $80^{\mathrm{b}}$ & $11.03^{\mathrm{c}}$ \\
L4 & $82^{\mathrm{a}}$ & $77^{\mathrm{a}}$ & $64^{\mathrm{ab}}$ & $82^{\mathrm{ab}}$ & $12.37^{\mathrm{abc}}$ \\
L5 & $82^{\mathrm{a}}$ & $73^{\mathrm{a}}$ & $70^{\mathrm{ab}}$ & $80^{\mathrm{b}}$ & $11.46^{\mathrm{bc}}$ \\
L6 & $92^{\mathrm{a}}$ & $79^{\mathrm{a}}$ & $70^{\mathrm{ab}}$ & $86^{\mathrm{ab}}$ & $13.09^{\mathrm{ab}}$ \\
\hline CV\% & 6.64 & 12.76 & 13.13 & 5.58 & 6.22
\end{tabular}

Note. *Vertical values with similar letters (lower case) show statistical similarity at the $95 \%$ confidence level.

Gaspar and Nakagawa (2002) evaluated the cultivar BN2, obtained rates of emergency between 5.08 and 6.17, depending on the lot evaluated. Thus, in the work described by the authors, the seedlings took approximately twice the speed to emerge. The accelerated ageing, obtained by the authors varied from 33 to $44 \%$, as well depending on the lot, being these $50 \%$ lower than those observed in the present study. In Table 2 , it can be observed that the ADR300 cultivars had no similarity with the data obtained by the authors for accelerated ageing (70 to $81 \%$ ), which can be explained by the difference in the cultivar (Common and BN2 used by the authors and ADR300 in the Present work). Of the lots studied, L3 presents better characteristics, being smaller EVI, ESS and AA.

Table 3 shows the values obtained by the electrical conductivity test. The test is based on the fact that the strength is related to the integrity of the cell membrane system and thereby assess the degeneracy status of the membranes. Thus, the higher the amount of damage present, the greater the amount of ions leached in the first hours of imbibition during the electrical conductivity test (Rosa, 2000). It is interesting to note that millet seeds with lower vigor probably present seed damage, thus, greater electrical conductivity due to the ions released through the damages.

It is important to note that the results of this test are affected by water quality, temperature, duration of imbibition time, degree of humidity and number of seeds tested, besides the genotype (Gaspar \& Nakagawa, 2002).

In relation to the period of seed imbibition and the electrical conductivity, it was observed that the time of 2 hours provided a lower result of electrical conductivity, being the evaluation that stood out the most, thus indicating a better physiological condition of the seed when treated at that time (Table 3). In addition, it is verified that with the increase of the imbibition time, the values obtained are higher, and, consequently, the damage to the seed is greater.

As for the volume factor in water, the volume in $75 \mathrm{~cm}^{3}$ showed the lowest values of electrical conductivity. The same was not observed by Gaspar and Nakagawa (2002) when evaluating millet seeds embedded in 50, 75 and $100 \mathrm{~cm}^{3}$ of water, and the last volume was the one with the highest values of electrical conductivity. The same authors also observed that with the reduction of the seed imbibition time, from 24 hours to two hours allows the same separation of the seed lots regarding and the physiological quality. Therefore, the two-hour evaluation is efficient for determination of seed vigor, besides, it allows the advantage of obtaining results in a shorter evaluation time. 
Table 3. Statistical analysis of the factors (water volume, imbibition time and lots of millet seeds of cultivar ADR300), obtained from the evaluation of the electrical conductivity (EC)

\begin{tabular}{ll}
\hline & $\mathrm{EC}\left(\mu \mathrm{S} \mathrm{cm} \mathrm{cm}^{-1}\right)$ \\
\hline Volume $\left(\mathrm{cm}^{3}\right)$ & $53.92^{\mathrm{b}}$ \\
75 & $35.29^{\mathrm{a}}$ \\
\hline Imbibition time $(\mathrm{h})$ & $32.73^{\mathrm{a}}$ \\
2 & $41.41^{\mathrm{b}}$ \\
4 & $49.78^{\mathrm{c}}$ \\
6 & $54.78^{\mathrm{d}}$ \\
8 & $36.33^{\mathrm{a}}$ \\
\hline Lots of seeds & $36.26^{\mathrm{a}}$ \\
1 & $55.19^{\mathrm{c}}$ \\
2 & $54.60^{\mathrm{c}}$ \\
3 & $37.88^{\mathrm{a}}$ \\
4 & $47.35^{\mathrm{b}}$ \\
5 & \\
6
\end{tabular}

Note. *Vertical values with similar letters (lower case) show statistical similarity at the 95\% confidence level, para cada fator (volume, imbibition time and lots seeds).

In Table 4, it was verified that the volume factor $\left(50\right.$ and $\left.75 \mathrm{~cm}^{3}\right)$ showed interaction, being the volume more indicated for the studied condition of $75 \mathrm{~cm}^{3}$, due to the lower conductivity, that is, a better physiological condition of the seed. Although the results showed a lower concentration of leached ions in the volume of $75 \mathrm{~cm}^{3}$, the better the results obtained when compared to the volume in $50 \mathrm{~cm}^{3}$.

It was possible to observe that lots 1, 2 and 5 presented greater vigor (lower values of electrical conductivity), and did not present significant difference between them. Lots 3 and 4 are less vigorous and do not differ from each other. Lot 6 differed statistically from the others, being placed as the intermediate vigor batch. In general, these results are consistent with the AA, ESS and EVI tests, in which lot 1 presented higher vigor and lot 3 less vigor.

Table 4. Statistical analysis of the electrical conductivity $\left(\mu \mathrm{S} \mathrm{cm}^{-1} \mathrm{~g}^{-1}\right)$ for the volume and volume of the factor factors, regardless of the imbibition time

\begin{tabular}{lllllll}
\hline Lots of seeds & \multicolumn{6}{l}{} \\
\hline Volume $\left(\mathrm{cm}^{3}\right)$ & 1 & 2 & 3 & 4 & 5 & 6 \\
\hline 50 & $44.40^{\mathrm{bA}}$ & $43.74^{\mathrm{bA}}$ & $66.54^{\mathrm{bC}}$ & $65.64^{\mathrm{bC}}$ & $45.83^{\mathrm{bA}}$ & $57.34^{\mathrm{bB}}$ \\
75 & $28.25^{\mathrm{aA}}$ & $28.78^{\mathrm{aA}}$ & $43.84^{\mathrm{aC}}$ & $43.56^{\mathrm{aC}}$ & $29.93^{\mathrm{aA}}$ & $37.36^{\mathrm{aB}}$
\end{tabular}

Note. *Vertical values with similar letters (lowercase) and horizontal values with similar letters (upper case) show statistical similarity at the $95 \%$ confidence level.

From the results of Tables 4 and 5 , it can be seen that lots 1,2 and 5 proved to be more vigorous. When compared with the values presented in Table 3, lots 1 and 2 stand out, therefore, they present better results for the tests of germination, first germination test count, emergence of seedlings in sand and index of emergency speed, thus presenting Similarities. 
Table 5. Statistical analysis of the electrical conductivity values $\left(\mu \mathrm{S} \mathrm{cm}{ }^{-1} \mathrm{~g}^{-1}\right)$ for time and batch factors, regardless of the volume used

\begin{tabular}{|c|c|c|c|c|c|c|}
\hline \multicolumn{7}{|c|}{ Lots of seeds } \\
\hline Time (h) & 1 & 2 & 3 & 4 & 5 & 6 \\
\hline 2 & $26.43^{\mathrm{aA}^{*}}$ & $25.38^{\mathrm{aA}}$ & $37.77^{\mathrm{aB}}$ & $43.14^{\mathrm{aB}}$ & $26.07^{\mathrm{aA}}$ & $37.57^{\mathrm{aB}}$ \\
\hline 4 & $33.34^{\mathrm{bA}}$ & $34.76^{\mathrm{bA}}$ & $49.46^{\mathrm{bCB}}$ & $53.56^{\mathrm{bC}}$ & $33.16^{\mathrm{bA}}$ & $44.15^{\mathrm{bB}}$ \\
\hline 6 & $41.79^{\mathrm{cA}}$ & $38.44^{\mathrm{bA}}$ & $63.68^{\mathrm{cC}}$ & $58.88^{\mathrm{cbC}}$ & $44.31^{\mathrm{cBA}}$ & $49.87^{\mathrm{cB}}$ \\
\hline 8 & $43.76^{\mathrm{cA}}$ & $46.47^{\mathrm{cA}}$ & $69.86^{\mathrm{dC}}$ & $62.82^{\mathrm{cB}}$ & $47.97^{\mathrm{cA}}$ & $57.80^{\mathrm{dB}}$ \\
\hline
\end{tabular}

Note. *Vertical values with similar letters (lowercase) and horizontal values with similar letters (upper case) show statistical similarity at the $95 \%$ confidence level.

By vigor tests, lots 3 and 4 were shown to be less vigorous, as compared to Table 3, which highlights lot 3 being the lowest force among all comparisons.

\section{Conclusion}

In the conditions under which the work was carried out, it can be concluded that the imbibition time and the volume influenced the electric conductivity of the millet seeds of the ADR300 cultivar, being recommended with a 2-hour time and a volume of $75 \mathrm{~cm}^{3}$.

\section{References}

Bhering, M. C., Dias, D. C. F. S., Vigial, D. S., \& Naveira, D. S. P. (2006). Accelerated aging test on pepper seeds. Brazilian Journal of Seeds, 28(3), 64-71. https://doi.org/10.1590/S0101-31222006000300010

Carneiro, M. A. C., Cordeiro, M. A. S., Assis, P. C. R., Moraes, E. S., Pereira, H. S., Paulino, H. B., \& Sousa, E. de. (2008). Phytomass production of different cover species and their instances of microbial nativity of cerrado soil. Bragantia, 67(2), 455-462. https://doi.org/10.1590/S0006-87052008000200021

Copeland, L. O., \& Mcdonald, M. B. (2001). Principles of seed science and technology (4th ed., pp. 165-192). Kluwer Massachusets: Academic Publishers.

Dutra, A. S., \& Vieira, R. D. (2006). Electric conduction test for an evaluation of the vigor of zucchini seeds. Brazilian Journal of Seeds, 28(2), 117-122. https://doi.org/10.1590/S0101-31222006000200015

Gaspar, C. M., \& Nakagawa, J. (2002). Test of electrical conductivity as a function of the imbibition period and temperature for millet seeds. Brazilian Journal of Seeds, 24(2), 82-89. https://doi.org/10.1590/S010131222002000100014

Maguire, J. D. (1962). Speed of germination-aid in relation evaluation for seedling emergence vigor. Crop Science, 2(2), 176-177. https://doi.org/10.2135/cropsci1962.0011183X000200020033x

Marcos-Filho, J. (1999). Seed vigor testing: Importance and use. In F. C. Krzyzanowski, R. D. Vieira, J. B. França Neto (Eds.), Seed vigor: Concepts and tests (Chap. 4, pp. 1.1-1.2). Londrina: Abrates.

Marcos-Filho, J. (2015). Seed vigor testing: An overview of the past, present and future perspective. Scientia Agricola, 72, 363-374. https://doi.org/10.1590/0103-9016-2015-0007

Marcos-Filho, J., Kikuti, A. L. P., \& Lima, L. B. (2009). Procedures for evaluation of soybean seed vigor, including an automated computer imaging system. Brazilian Journal of Seeds, 31(1), 102-112. https://doi.org/ 10.1590/S0101-31222009000100012

Martins, C. C., Martinelli-Seneme, A., Castro, M. M., Nakagawa, J., \& Cavariani, C. (2002). Methods of comparison to evaluate broccoli seed lot vigor. Brazilian Journal of Seeds, 24(2), 96-101. https://doi.org/ $10.1590 / \mathrm{S} 0101-31222002000100016$

Ministry of Agriculture, Livestock and Supply. (2009). Rules for seed analysis (p. 395). Brasília, Brazil.

Peske, F. B., \& Novembre, A. D. L. C. (2010). Physiological conditioning of millet seeds. Brazilian Journal of Seeds, 32. https://doi.org/10.1590/S0101-31222010000400015

Rosa, S. D. V. F. (2000). Physiological quality and enzyme activity in corn seeds submitted to artificial drying. Brazilian Journal of Seeds, 22(1), 54-63. https://doi.org/10.17801/0101-3122/rbs.v22n1p177-184 
Silva, V. N., \& Cicero, S. M. (2014). Evaluation of vigor of tomato seeds during storage by means of computerized analysis of seedling images. Semina: Agrarian Sciences, 35(4), 2317-2326. https://doi.org/ 10.5433/1679-0359.2014v35n4Suplp2317

Vazquez, G. H., Lema, A. C. F., \& Granzotto, R. (2011). Dry phytomass production of eight plant species in two sowing seasons in the northwest region of the state of São Paulo. Nucleus, 8, 1-16. https://doi.org/10.3738/ 1982.2278.499

Vieira, R. D., \& Krzyzanowski, F. C. (1999). Electrical conductivity test. In F. C. Krzyzanowski, R. D. Vieira, \& J. B. França Neto (Eds.), Seed vigor: Concepts and testicles (Chap. 4, pp. 1-26). Londrina: Abrates.

Vieira, R. D., Penariol, A. L., Perecin, D., \& Panobianco, M. (2002). Electrical conductivity and initial water content of soybean seeds. Pesquisa Agropecuária Brasileira, 37(9), 1333-1338. https://doi.org/10.1590/ S0100-204X2002000900018

\section{Copyrights}

Copyright for this article is retained by the author(s), with first publication rights granted to the journal.

This is an open-access article distributed under the terms and conditions of the Creative Commons Attribution license (http://creativecommons.org/licenses/by/4.0/). 